\title{
Аналіз впливу спеціалізації підприсмства на ефективність виробництва лікарських культур
}

\begin{abstract}
В умовах сьогодення лікарські рослини - ие не тільки джерело рослинної сировини для величезної кількості лікувальних $і$ профілактичних засобів, а й джерело доходу для окремих сільськогосподарських підприсмств $i$ домогосподарств населення. Проте, незважаючи на значний попит, який нині існує на лікарські рослини, обсяги їх виробництва в нашій державі дуже малі. В зв'язку з ичим необхідними є дослідження розвитку лікарського рослинництва та факторів, які на нього впливають. Метою статі є аналіз впливу спеціалізації підприємства на виробництво лікарських культур. Для досягнення поставленої мети виконані такі завдання: здійснено розподіл господарств на групи за загальною посівною площею рослин лікарських, пряних та ефіроолійних, розподіл досліджуваних господарств за посівною площею рослин лікарських (без ефіроолійних і пряних) і виконано аналіз групування. Дослідженням було охоплено 213 сільськогосподарських підприємств, які функиіонували в 2017 р. в сільському господарстві та звітувалися в державні статистичні органи як виробники лікарських рослин, враховуючи пряні та ефіроолійні. Таким чином, у межах иьього дослідження застосовано методи статистичного групування та економічного аналізу. Застосування зазначених методів дозволило виявити, щчо за обсягами виробництва лікарських рослин (без ефіроолійних і пряних) у сфері сільськогосподарського виробництва лідирують великі підприємства із посівними площами більще 100 га, а за рівнем урожайності лідерами є дрібні підприємства. За розмірами виручки лідирують середні й великі підприємства. Відповідно, спеціалізація підприємства в сфері лікарського рослинництва суттєво впливає на розвиток виробництва лікарських культур. Можна вважати чинник спеціалізаџії одним із орієнтирів ефективного розвитку лікарського рослинництва в умовах сьогодення.
\end{abstract}

Ключові слова: лікарське рослинництво; спеціалізація підприємства; ефективність виробництва.

Постановка проблеми. В умовах сьогодення з кожним днем усі більшої актуальності в Україні та світі набуває виробництво лікарських рослин. Справа в тому, що людство після тривалого періоду лікування синтетичними препаратами зіткнулося з безліччю негативних наслідків. Одним із найбільш розповсюджених негативних наслідків лікування синтетичними препаратами є алергія, на яку страждає нині за різними оцінками 40-80 \% людей у світі. Крім того, зростання попиту на лікарські рослини обумовлюється тим, що в світі все більш популярним стає здоровий спосіб життя. Наприклад, у Німеччині в останні роки населення віддає перевагу трав'яним чаям. Звідси - потреба у лікарських травах, які тільки в Україні німецькі підприємці готові купувати понад 40 тис. т на рік. Вагомим аргументом на користь виробництва лікарських культур є й те, що майже 80 \% ліків від серцевих хвороб виготовляються на основі рослинної сировини - іншої альтернативи людство поки що не винайшло. Це тільки окремі чинники, що обумовлюють необхідність розвитку виробництва лікарських рослин серед величезної кількості. Тому пошук оптимальних шляхів розвитку лікарського рослинництва та пошук факторів, які здатні підвищити ефективність виробництва лікарських рослин у сучасних умовах розвитку, є нагальною ефективністю. Одним із таких факторів, як свідчать численні дослідження, $\epsilon$ спеціалізація підприємств.

Аналіз останніх досліджень і публікацій. Питання розвитку виробництва лікарських культур і торгівлі ними досліджувало багато вітчизняних i зарубіжних учених. Причому, дослідження здійснювалися й здійснюються як у розрізі світу, так і в розрізі окремих країн. Наприклад, науковці Pyakurel D., Bhattarai Sharma I., Smith-Hall C. досліджували зміни в торгівлі лікарськими рослинами в Непалі за останні 17 років і визначили основні фактори, що зумовлюють ці зміни [9].

Використанню лікарських рослин у загальному та перспективам їх виробництва приділяли увагу індійські вчені Refaz Ahmad Dar, Mohd Shahnawaz, Parvaiz Hassan Qazi [8].

Багато європейських учених досліджує питання ефективності виробництва лікарських рослин. Так Ivan Salamon досліджував питання культивації лікарських культур у Словаччині [10]. Dagmar Lange приділяла увагу виробництву й торгівлі лікарськими рослинами в різних країнах світу, a Maria Stoyanova досліджувала тенденції використання недеревних лісових рослин у Болгарії [7, 11]. 
Разом із тим, зважаючи на те, що на українському ринку попит на лікарські рослини все ще перевищує пропозицію й ця продукція має значний експортний потенціал, питання розвитку виробництва лікарських рослин і підвищення його ефективності вимагає подальших наукових досліджень.

Метою публікації є аналіз впливу спеціалізації підприємства на виробництво лікарських культур.

Викладення основного матеріалу. Дослідженням було охоплено 213 сільськогосподарських підприємств, які функціонували в 2017 р. в сільському господарстві та звітувалися в державні статистичні органи як виробники лікарських рослин, враховуючи пряні та ефіроолійні. Для порівняння, у 2017 р. в Україні в сільському господарстві діяло 44998 підприємств [1]. Остання цифра свідчить, що виробництвом лікарських рослин у нашій державі займається зовсім незначна кількість сільськогосподарських підприємств.

Перш за все зауважимо, що досліджувані підприємства для вирощування лікарських рослин станом на 2017 рік використовували 16567,8 га сільськогосподарських угідь. 3 них найбільше було відведено на вирощування ефіроолійних культур, а саме - 8496, 1 га $(51,3$ \%) сукупно в усіх підприємствах, найменше - на пряні культури (табл. 1).

Оскільки будь-яке дослідження 3 використанням групувань передбачає визначення мети [2], виконане групування також здійснювалося не просто так. Із метою розділити складну, неоднорідну сукупність підприємств виробників лікарських рослин на однорідні всередині, проте істотно різні між собою групи всі досліджувані підприємства були поділені на 5 груп, залежно від посівних площ лікарських рослин - від менше 10 га до більше за 100 га. Найбільше підприємств у сукупності досліджуваних, а саме 71, або 33,3 \% під лікарськими рослинами мають 40,1-100 га й на них припадає 29,2 \% посівної площі. Другою за чисельністю є група підприємств, у яких під лікарські рослини відведено до 10 га - таких налічується 41 із 213, або 19,2 \% і на ці підприємства припадає 223,2 га, або1,3 \% усіх посівних площ лікарських рослин. При цьому виявлено, що на 40 господарств (18,8 \% від загальної кількості досліджуваних підприємств), які для вирощування лікарських рослин використовують більше 100 га, припадає 9948,6 га, або 60 \% від загальної посівної площі під лікарськими рослинами в досліджуваних підприємствах.

Це є свідченням того, що, на нашу думку: в сфері лікарського рослинництва сформовано ядро крупних спеціалізованих підприємств; серед виробників лікарських рослин функціонує низка підприємств малого та середнього розміру, крім того, припускаємо, значна частина сільськогосподарських підприємств використовує лікарські рослини в сівозмінах або займається вирощуванням лікарських рослин як супутньою діяльністю; значний сегмент на цьому ринку займають міні-ферми.

При цьому середній розмір посівної площі у великих підприємствах становить 248,7 га, в середніх 68,2, а в так званих міні-фермах - 5,4. Що стосується видового співвідношення лікарських рослин, то за основу було прийнято розподіл, який використовує Державна служба статистики України. Зокрема, під час групування було виокремлено суто лікарські рослини, пряні та ефіроолійні. Як виявлено під час дослідження, в 2017 р. вітчизняними виробниками лікарського рослинництва найбільше посівних площ було відведено під ефіроолійні лікарські рослини - 51,3\% в цілому у всіх досліджуваних підприємствах, на другому місці - 29,8 \% суто лікарські рослини й на третьому місці за посівними площами - 19,0\% пряні культури (табл. 1).

Що стосується обсягів виробництва, то проведений аналіз свідчить, що великі, середні й малі підприємства лідирують за виробництвом ефіроолійних рослин, а дрібні з посівними площами до 10 га найбільше виробляють суто лікарських культур. Можемо це частково пояснити тим, що врожайність лікарських рослин у групах досліджуваних підприємств є найвищою саме в міні-фермах із посівною площею до 10 га. Зокрема, якщо в групі великих підприємств урожайність суто лікарських рослин склала 6,6 ц/га, то в групі дрібних підприємств - 17,5. У розрізі пряних і ефіроолійних культур урожайність $€$ найвищою в малих підприємствах із посівною площею від 10 до 20 га - 10,3 та 8,7 ц/га відповідно.

Як свідчить світовий досвід, вища врожайність сільськогосподарських культур у малих і дрібних господарствах або в так званих родинних фермах є типовим явищем. Так експерти зазначають, що, як правило, родинні ферми орієнтовані на високу врожайність, а великі аграрні підприємства, в першу чергу, на комерційну ефективність. Родинні ферми в розвинутих країнах вирощують більшу масу продукції на 1 га, аграрні господарства мають більший прибуток із 1 га [5].

Останнє пов'язано з тим, що ретельний обробіток родиною власної землі практично завжди дає кращий результат, аніж обробіток найманими працівниками чужої. Світовий багаторічний досвід свідчить, що: 1) меншу за площею ділянку, як правило, обробляють більш ретельно, ніж більшу; 2) жодна механізація праці не спроможна компенсувати різницю у врожайності; 3) врожайність ферми має прямо обернену залежність від площі сільськогосподарських угідь у її власності - що менша площа міні-господарства, тим вища врожайність сільськогосподаських культур. Як виявлено під час дослідження, такі закономірності притаманні й галузі лікарського рослинництва. 
Розподіл господарств за загальною посівною площею рослин лікарських, пряних та ефіроолійних, 2017 p. *

\begin{tabular}{|c|c|c|c|c|c|c|}
\hline \multirow[b]{2}{*}{ Показник } & \multicolumn{5}{|c|}{ Групи за посівною площею рослин } & \multirow{2}{*}{$\begin{array}{c}\text { Усі } \\
\text { госпо- } \\
\text { дарст- } \\
\text { ва } \\
\end{array}$} \\
\hline & до 10 га & $10,1-20$ га & 20,1-40 га & $\begin{array}{c}40,1-100 \\
\text { га }\end{array}$ & $\begin{array}{c}\text { більше } \\
\text { за } 100 \text { га }\end{array}$ & \\
\hline Кількість господарств & 41 & 22 & 39 & 71 & 40 & 213 \\
\hline \multicolumn{7}{|c|}{ Посівна площа, га } \\
\hline Усього & 223,2 & 359,8 & 1196,0 & 4840,2 & 9948,6 & 16567,8 \\
\hline у т.ч. лікарські рослини & 95,3 & 114,7 & 399,3 & 1219,6 & 3101,1 & 4930,0 \\
\hline пряні & 29,2 & 89,4 & 213,2 & 948,9 & 1861,1 & 3141,7 \\
\hline ефіроолійні & 98,7 & 155,7 & 583,6 & 2671,7 & 4986,4 & 8496,1 \\
\hline \multicolumn{7}{|c|}{ Посівна площа в середньому 1 господарства, га } \\
\hline Усього & 5,4 & 16,4 & 30,7 & 68,2 & 248,7 & 77,8 \\
\hline у т. ч. лікарські рослини & 2,3 & 5,2 & 10,2 & 17,2 & 77,5 & 23,1 \\
\hline пряні & 0,7 & 4,1 & 5,5 & 13,4 & 46,5 & 14,7 \\
\hline ефіроолійні & 2,4 & 7,1 & 15,0 & 37,6 & 124,7 & 39,9 \\
\hline \multicolumn{7}{|c|}{ Видові співвідношення, \% } \\
\hline лікарські рослини & 42,7 & 31,9 & 33,4 & 25,2 & 31,2 & 29,8 \\
\hline пряні & 13,1 & 24,8 & 17,8 & 19,6 & 18,7 & 19,0 \\
\hline ефіроолійні & 44,2 & 43,3 & 48,8 & 55,2 & 50,1 & 51,3 \\
\hline \multicolumn{7}{|c|}{ Виробництво, Ц } \\
\hline лікарські рослини & 1672 & 944 & 2781 & 11754 & 20388 & 37539 \\
\hline пряні & 192 & 923 & 1328 & 5691 & 15145 & 23279 \\
\hline ефіроолійні & 747 & 1361 & 4097 & 15024 & 32485 & 53714 \\
\hline \multicolumn{7}{|c|}{ Урожайність, ц/га } \\
\hline лікарські рослини & 17,5 & 8,2 & 7,0 & 9,6 & 6,6 & 7,6 \\
\hline пряні & 6,6 & 10,3 & 6,2 & 6,0 & 8,1 & 7,4 \\
\hline ефіроолійні & 7,6 & 8,7 & 7,0 & 5,6 & 6,5 & 6,3 \\
\hline
\end{tabular}

*складено автором за даними Державної служби статистики України [3]

Аналіз розподілу досліджуваних господарств за посівною площею лікарських рослин (без ефіроолійних і пряних) (табл. 2) свідчить, що, попри найвищу врожайність і досить великі обсяги виробництва лікарських культур дрібними господарствами, найбільше їх виробляють великі господарства $з$ посівними площами більше 100 га. Так у 2017 р. ними було вироблено 19649,7 ц, або 52,3 \% від загального обсягу виробництва. Це попри те, що група підприємств виробників лікарських рослин із посівною площею більше 100 га була найменшою й складала 11 одиниць та попри те, що підприємства цієї групи мали найнижчу врожайність лікарських культур - 6,7 ц/га.

У сфері реалізації лікарських рослин лідирують середні підприємства - 9576 ц у 2017 р., або 62,3 \% від усієї реалізованої продукції, що, ймовірно, обумовлюється найбільшою кількістю підприємств у цій групі (табл. 2).

На другому місці за обсягами реалізації - великі підприємства. Привертають увагу деякі розбіжності між обсягами виробництва й обсягами реалізації в усіх досліджуваних групах підприємств. Так у групі дрібних господарств у 2017 р. було вироблено 1672 ц лікарських рослин, а реалізовано лише 186 ц. У групі середніх і великих підприємств обсяги реалізації лікарських рослин також менші за обсяги виробництва. Це можна пояснити декількома причинами. По-перше, вироблену продукцію не вдалося реалізувати через низьку якість; по-друге, вироблену продукцію не змогли реалізувати й залишили на зберіганні; по-третє, підприємства самі виробляють кінцевий продукт (трав'яні збори, чаї тощо) та реалізують його, а не сировину.

У групі дрібних підприємств ситуація дещо інша - в 2017 р. було реалізовано лікарських рослин на 7 \% більше, ніж було вироблено. Це також можна пояснити декількома причинами: по-перше, ймовірно було реалізовано продукцію, вироблену в попередні періоди; по-друге, на реалізацію було спрямовано продукцію, вироблену власними силами та прийняту в різноманітних заготівельників. 
Розподіл досліджуваних господарств* за посівною площею рослин лікарських (без ефіроолійних і пряних), 2017 р.

\begin{tabular}{|c|c|c|c|c|c|c|c|c|c|}
\hline \multirow[b]{2}{*}{$\begin{array}{c}\text { Групи за } \\
\text { площею } \\
\text { лікарських } \\
\text { рослин, га }\end{array}$} & \multirow[b]{2}{*}{$\begin{array}{l}\text { Кіль- } \\
\text { кість } \\
\text { госпо- } \\
\text { дарств }\end{array}$} & \multirow{2}{*}{$\begin{array}{c}\text { Середня } \\
\text { площа } \\
\text { лікарських } \\
\text { рослин } \\
\text { на } 1 \\
\text { господар- } \\
\text { ство }\end{array}$} & \multicolumn{3}{|c|}{ Виробництво } & \multicolumn{4}{|c|}{ Реалізація } \\
\hline & & & $\begin{array}{c}\text { Площа, } \\
\text { га }\end{array}$ & $\begin{array}{c}\text { Вироб- } \\
\text { ництво, ц }\end{array}$ & $\begin{array}{c}\text { Урожай- } \\
\text { ність, } \\
\text { ц/га }\end{array}$ & $\begin{array}{c}\text { Обсяг, } \\
\text { ц }\end{array}$ & $\begin{array}{l}\% \text { до } \\
\text { вироб- } \\
\text { ництва }\end{array}$ & $\begin{array}{c}\text { Вартість, } \\
\text { тис. грн }\end{array}$ & $\begin{array}{l}\text { Ціна } \\
1 \text { ц, } \\
\text { грн }\end{array}$ \\
\hline до 10 & 18 & 5 & 95,3 & 1672,3 & 17,5 & 186 & 11,1 & 313 & 1683 \\
\hline $10,1-20$ & 10 & 16 & 163,7 & 1418,5 & 8,7 & 1518 & 107,0 & 2537 & 1671 \\
\hline $20,1-40$ & 14 & 32 & 447,4 & 3475,2 & 7,8 & 521 & 15,0 & 1101 & 2112 \\
\hline $40,1-100$ & 20 & 64 & 1282,5 & 11323,5 & 8,8 & 9576 & 84,6 & 14405 & 1504 \\
\hline $\begin{array}{c}\text { більше } \\
100\end{array}$ & 11 & 267 & 2941,1 & 19649,7 & 6,7 & 3565 & 18,1 & 9596 & 2692 \\
\hline $\begin{array}{c}\text { Усі госпо- } \\
\text { дарства }\end{array}$ & 73 & 68 & 4930,0 & 37539,2 & 7,6 & 15366 & 40,9 & 27952 & 1819 \\
\hline
\end{tabular}

*господарства, які вирощують лікарські рослини [3]

Відповідно до обсягів реалізації найбільше в 2017 р. виручили від продажу лікарських рослин 20 середніх підприємств - 14495 тис. грн, або 51,5 \%, а найменше - дрібні підприємства - 313 тис. грн, або 1,1 \% від загальної вартості реалізованої продукції. Середня ціна реалізації лікарських рослин у 2017 р. становила 1819 грн/ц, а найвищою ціна реалізації 1 ц лікарських рослин у 2017 р. була в групі великих підприємств. Вважаємо, що, оскільки зазначені підприємства, ймовірно, є спеціалізованими, то вони мають низку переваг, які й обумовлюють вищу ціну реалізації лікарських рослин. По-перше, великі підприємства, ймовірно, мають кращі потужності для сушіння й доробки сировини. Відповідно, це означає, що великі підприємства виробники лікарських рослин можуть досягти вищої якості виробленої продукції. По-друге, великі підприємства, що виробляють значні обсяги лікарських рослин, можуть запропонувати переробним підприємствам, фармацевтичним фабрикам і посередникам великі партії якісної продукції, за яку покупці дають вищу ціну. Зазначимо, що така ситуація є типовою для сільського господарства в цілому. Так, згідно зі статистичними даними, у 2017 р. найбільш прибутковими були саме великі підприємства, частка яких у загальній кількості становила 88,9 \% [6].

Важливим показником ефективного землекористування в умовах сьогодення є структура посівних площ [4]. У структурі посівних площ лікарських рослин за видами, керуючись даними Державної служби статистики, переважає ромашка та «інші лікарські рослини». Зважаючи на те, що вітчизняне лікарське рослинництво нині перебуває на етапі зростання, група «інші лікарські рослини», є досить потужною й включає велику кількість культур - подорожник, кульбабу, ехінацею, родіолу рожеву, розторопшу, васильки тощо. Ромашки лікарської найбільше виробляють дрібні підприємства - 33,1 \%, на другому місці - середні підприємства - 32 \%. У той час, як малі підприємства найбільше - 74,8 \% виробляють інших лікарських рослин. Варто зауважити, що видове різноманіття лікарських рослин, які вирощуються в тому чи іншому підприємстві залежить від низки факторів - природно-кліматичних умов, попиту, каналів реалізації тощо.

Висновки. Таким чином, у результаті аналізу групувань підприємств за посівною площею лікарських культур виявлено чіткі залежності від цього фактора показників економічної ефективності виробництва лікарських рослин у сільськогосподарських підприємствах, що здійснюють свою діяльність у різних регіонах нашої держави. Зокрема, за обсягами виробництва лікарських рослин (без ефіроолійних і пряних) лідирують великі підприємства із посівними площами більше за 100 га, а за рівнем урожайності лідерами є дрібні підприємства. За розмірами виручки лідирують середні й великі підприємства. Відповідно, спеціалізація підприємства в сфері лікарського рослинництва досить суттєво впливає на розвиток виробництва лікарських культур. Щоправда, в умовах сьогодення крупних спеціалізованих підприємств у галузі лікарського рослинництва вкрай мало, тому на часі подальші дослідження стосовно розвитку цього напряму діяльності.

\section{Список використаної літератури:}

1. Волкова Н.А. Аналітична оцінка фінансового стану підприємств сільського господарства / Н.А. Волкова // Вісник ЖДТУ / Серія : Економіка, управління та адміністрування. - 2018. - № 4 (86). - С. 3-7. 
2. Глібов Р.В. Групування економічних показників: теорія і практика / Р.В. Глібов // Вісник ЖДТУ / Серія : Економічні науки. - 2016. - № 4 (78). - С. 152-157.

3. Державна служба статистики України. - К., 2018 [Електронний ресурс]. - Режим доступу : http://www.ukrstat.gov.ua.

4. Кобилинська Т.В. Статистичне оцінювання галузі рослинництва / T.В. Кобилинська // Вісник ЖДТУ / Серія : Економічні науки. - 2018. -№ 1 (83). - С. 66-70.

5. Маркитаненко С. Ефективні фермери чи неефективні агрохолдинги? / С.Маркитаненко [Електронний pecypc]. - Режим доступу : https://latifundist.com/193-efektivn-fermeri-chi-neefektivn-agroholdingi.

6. Ткачук Г.Ю. Сучасні тенденції розвитку сільського господарства в контексті забезпечення його економічної безпеки / Г.Ю. Ткачук // Вісник ЖДТУ / Серія : Економіка, управління та адміністрування. - 2019. № 1 (87). - C. 42-47.

7. Lange D. Medicinal and Aromatic Plants: Trade, Production, and Management of Botanical Resources / D.Lange [Електронний ресурс]. - Режим доступу : https://www.researchgate.net/publication/267772013.

8. Refaz Ahmad Dar General overview of medicinal plants: A review / Refaz Ahmad Dar, Mohd Shahnawaz, Parvaiz Hassan Qazi [Електронний pecypc]. http://www.phytopharmajournal.com/Vol6_Issue6_08.pdf.

9. Pyakurel D. Patterns of change: The dynamics of medicinal plant trade in far-western Nepal / Pyakurel D, Bhattarai Sharma I, Smith-Hall C. [Електронний ресурс]. - Режим доступу : https://www.ncbi.nlm.nih.gov/pubmed/29885362.

10. Salamon I. The cultivation and processing of medicinal plants in Slovakia / I.Salamon [Електронний ресурс]. Режим доступу : https://www.researchgate.net/publication/283566447.

11. Stoyanova M. Trends in the Use of Non-Wood Forest Products in Bulgaria / M.Stoyanova [Електронний pecypc]. - Режим доступу : ttps://silvabalcanica.files.wordpress.com/2012/11/m_stoyanova.pdf.

\section{References:}

1. Volkova, N.A. (2018) «Analitychna ocinka finansovogo stanu pidpryjemstv sil's'kogo gospodarstva», Visnyk ZhDTU, Serija Ekonomika, upravlinnja ta administruvannja, Vol. 4 (86), pp. 3-7.

2. Glibov, R.V. (2016) «Grupuvannja ekonomichnyh pokaznykiv: teorija i praktyka», Visnyk ZhDTU, Serija Ekonomichni nauky, Vol.4 (78), pp. 152-157.

3. Derzhavna sluzhba statystyky Ukrai'ny (2018), Kyiv, [Online], available at: http://www.ukrstat.gov.ua

4. Kobylyns'ka, T.V. (2018). «Statystychne ocinjuvannja galuzi roslynnyctva», Visnyk ZhDTU, Serija Ekonomichni nauky, Vol. 1 (83), pp. 66-70.

5. Markytanenko, S. (2019), Efektyvni fermery chy neefektyvni ahrokholdynhy?, [Online], available at: https://latifundist.com/193-efektivn-fermeri-chi-neefektivn-agroholdingi

6. Tkachuk, G.Ju. (2019), «Suchasni tendencii' rozvytku sil's'kogo gospodarstva v konteksti zabezpechennja jogo ekonomichnoi' bezpeky», Visnyk ZhDTU, Serija Ekonomichni nauky, Vol. 1 (87), pp. 42-47.

7. Lange, D., Medicinal and Aromatic Plants: Trade, Production, and Management of Botanical Resources, [Online], available at: https://www.researchgate.net/publication/267772013

8. Refaz Ahmad Dar, Mohd Shahnawaz, Parvaiz Hassan Qazi, General overview of medicinal plants: A review, [Online], available at: http://www.phytopharmajournal.com/Vol6_Issue6_08.pdf

9. Pyakurel, D., Bhattarai Sharma, I. and Smith-Hall, C., Patterns of change: The dynamics of medicinal plant trade in far-western Nepal, [Online], available at: https://www.ncbi.nlm.nih.gov/pubmed/29885362

10. Salamon, I., The cultivation and processing of medicinal plants in Slovakia, [Online], available at: https://www.researchgate.net/publication/283566447

11. Stoyanova, M., Trends in the Use of Non-Wood Forest Products in Bulgaria, [Online], available at: ttps://silvabalcanica.files.wordpress.com/2012/11/m_stoyanova.pdf

Мірзоєва Тетяна Володимирівна - кандидат економічних наук, доцент, доцент кафедри економіки підприємства ім. проф. І.Н. Романенка Національного університету біоресурсів і природокористування України.

https://orcid.org/0000-0002-0034-6138.

Наукові інтереси:

- розвиток галузі рослинництва загалом і лікарського рослинництва зокрема;

- економіка виробництва лікарських рослин.

E-mail: mirzoeva2018@ukr.net. 